\title{
低気圧直流放電中の乱流ポテンシャル ステップ現象の研究
}

$\begin{array}{llllll}\text { 正員園 田 } & \text { 義 人 } & \text { (九州大) } \\ \text { 正員 未 次 } & \text { 祐 介 } & \text { (九州大) } \\ \text { 正員 村 岡 克 紀 (九州大) } \\ \text { 正員 赤 崎 正 則 (九州大) }\end{array}$

\section{1. まえがき}

種々の条件下の放電によるプラズマ発生装置には， しばしば局所的な強電界部が発生する。その局所強電 界による電位の階段状の変化（以後，ポテンシャルス テップと呼ぶ）は，放電ないしはプラズマの維持作用 と密接阔係しており，応用上も重要であるが，同時 亿放電の基礎過程としてあ興味深い現象である。

その中で，例えば数 Torr 前後の正力で，外観的に しま状の局所発光を伴って䍐われるストリエーション と呼ばれるポテンシャルステップ現象は，各種の実 用放電管や氮体レーザなどとの関連でよく知られてい $ろ^{(1) \sim(3)}$ 。その発生機構㧍上び性質は, 電旅不安定性 による波動現象としてよく理解されており，電離波 (Ionization Wave) とむ呼ばれている。

他方，0.1 mTorr 程度以下の無衝突プラズマ中で発 生するポテンシャルステップは，ダブルレヤーと呼ば れ，開放端系核融合ブラズマ装置におけるタンデムポ テンシャル形成や，宇宙プラズマ中ての電子加速機構 お上び電磁波放射機構などと関連して最近注目されて いる。そこでの電界維持機構について，数多くの実験 や計算機シミュレーションによる研究がなされている がまだ不明の点が多い(4)。

また，1 $\mathrm{mTorr}$ 以下の低圧力放電中では，印加電死

Studies of Turbulently Produced Potential Step Phenomena in Low-Pressure DC Discharge. By Yoshito Sonoda, Member, Yusuke Suetsugu, Member, Katsunori Muraoka, Member \& Masanori Akazaki, Member (Interdisciplinary Graduate School of Engineering Scieaces, Kyushu University).

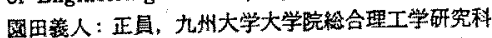
末次诸介: 正員, 九州大学大学踪棯合理工学研究科 村网克紀: 正員, 九州大学大学院稳合理工学研究科

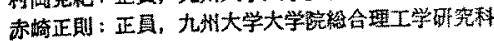

を上げていくと，放電電流の上限が現われる琴象〔電 流制限 (Current Limitation)ないしアーク枯渴（Arc Starvation)と呼代れているがあり，その際，プラ ズマ中にポテンシャルステップが観測されている(4)。

著者らは，前記の代表的な二つの王力領域の中間王 力領域 (1 10 m Torr) での熱陰極形直流放電中に, 電䨆を伴った，かつプラズ マ不安定性が支配的な乱 流形ポテンシャルステップ (Turbulently Produced Potential Step, 以下 TPS と略記) が発生することを 見いだした (5)ー(7)。本諭文は，乙の発生・維持譏满を明 らかにするとと老目的とするむので，まずTPS 領域 でのプラズマの構造や特性, ならびにプラズマ乱れに 関する测定結果を述べる。次に，てれらの測定結果を 基に，TPS の発生・維持機構㧍よびプラズマと放電の 諸特性が，プシズマ不安定性によって説明できること を示す。更に，局所磁界を印加して放電空間の電子密 度を変化させる実験によって，上記の結諭加努当なと と，およびこの局所磁界の印加によって TPS の発生 と制御が可能なととを示す。

\section{2. 実験装置と方法}

〈2.1〉 実験装置 実駼装置の概略学図1亿示す。 放電管は内经 $90 \mathrm{~mm}$ ，電極間距離は $600 \mathrm{~mm}$ である。 险極は直经 $20 \mathrm{~mm}$ の円筒形 (材質, ニッケル)で， その前面化酸化膜を準布した傍熱形熱陰極である。陽 極は直径 $60 \mathrm{~mm}$ のタンダステン平板円筒である。使 用気体はアルゴン (Ar) で, 压力籁围は 0.4〜10 m Torr 上した。比較のため登菜 $(\mathrm{N})$, 水秦 $(\mathrm{H})$, ヘリウム (He)の各がスの実験も行なった。電源は定電流・定電 压形安定化電源で，最大定格 $500 \mathrm{~mA}, 600 \mathrm{~V}$ であ る。TPS の制御の際に用いた遂界用コイル（全横幅

昭 $58-11$ 


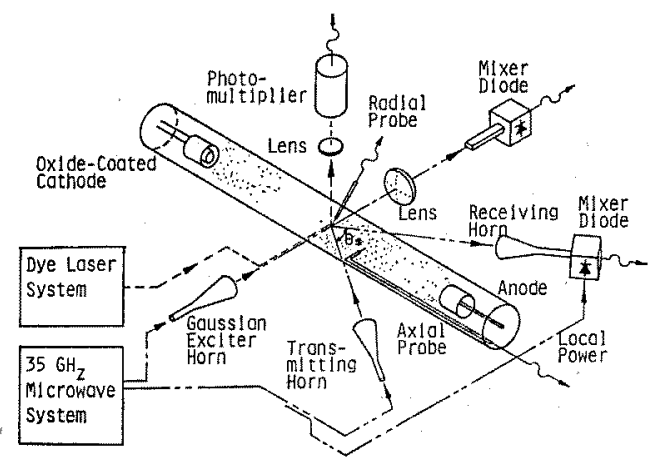

図 1 実験装置の配置

Fig. 1. Experimental setup.

$30 \mathrm{~mm}, 32$ 回巻) は，陰極より $190 \mathrm{~mm}$ の位置に放電 管外周に設置している。

プラズマ諸量の測定には，軸方向に可動な円柱プロ ーブ (直径 $0.1 \mathrm{~mm}$, 長さ $3 \mathrm{~mm}$ ) および平面プローブ （直径 $3.5 \mathrm{~mm}$ ) と径方向に可動なプローブを, 軸方向 に $20 \mathrm{~mm}$ おきに(TPS 部では $10 \mathrm{~mm}$ おきに) 設置 した。空間電位の測定にはエミッシブプローブを用 い，電子の一次元速度分布関数の測定には平面プロー ブのバイアス電圧人微小交流電圧を印加し，プローブ 電流電圧特性の一次微分を求める，いわ的交流重畳 法 ${ }^{(8)}$ を採用した。なお，プローブ占有領域内での電子 密度の经方向変化は十分に小さく，一次元速度分布測 定への影響は無視できる。電子密度の測定には，管軸 に平行に向けた面プローブを用い，飽和点(電子電流) の決定にはプローブ電流電圧特性の折れ曲がり点の判 定と共に，エミッシブプローブによる空間電位の測定 を併用し，十分な精度が得られるようにした。プラズ マ波動の測定には，電子飽和領域にバイアスした円柱 プローブおよび $35 \mathrm{GHz}$ マイクロ波のフラウンホーフ ア回折法を用いた。フラウンホーファ回折法について は，最近著者らがマイク口波領域で技術的確立を行な っており ${ }^{(9)}$ ，以下に簡単にその方法を示す。

〈2-2〉 フラウンホーファ回折計測ウスビー ムをプラス゚マ中に入射，そのビームウェストをプラ ズマ波動が垂直に通過するとき，受光側レンズの前方 焦点面上では，次式で与えられる信号強度が得られ $\zeta^{(10)(11) 。}$

$$
\begin{aligned}
I_{a c}^{(1)}= & |B|^{2} \Delta \phi e^{-u^{2}}\left\{e^{-(u-\theta)^{2}}\right. \\
& \left.-e^{-(u+\theta)^{2}}\right\} \cos \omega_{p} t \ldots \ldots .
\end{aligned}
$$

ここで, $|B|^{2}=\left(2 P_{0} / \pi w_{f}^{2}\right) \exp \left\{-2\left(y_{f} / w_{f}\right)^{2}\right\}$, $\Delta \phi=\tilde{n}_{c} r_{e} \lambda \Delta d, u \equiv x_{f} / w_{f}, \theta \equiv k_{p} w_{0} / 2, P_{0}: 入$ 射全パワー, $\tilde{n}_{\bullet}$ : 電子密度の仍らぎの振幅, $r_{\text {, }}$ : 電子古典半径, $\lambda:$ 入射電磁波波長, $\Delta d$ :
プラズマ波動の 横幅, $\left(x_{f}, y_{f}\right), w_{f}$ : 受光レ ンズの前方焦点面上での座標扰よ゙ビーム輻,

$k_{p}, \omega_{p}: フ^{0} ラ ス ゙ マ$ 波動の波数および周波数, $w_{0}:$ ビームウェスト幅

$I_{a c}{ }^{(1)}$ の空間的プロファイルは，プラズマ波動飞依 存した二山分布で， その極大点の規格化座標 $u_{m}$ (三 $x_{f m} / w_{f}$ ) 估規格化波数 $\theta$ 之一定の関係（文献 $(9)$ 参 照〕を有する。従って，前方焦点面における $\omega_{p}$ 振動 成分の空間的強度分布を測定すれば，極大点の座標加 らプラズマ波動の波数を求めることができる。

なお，本実験の測定対象であるポテンシャルステ ップ領域はかなりの電子密度こう配を生じているが, 密度乙う配 $\left\{n_{\sigma x}=n_{\mathrm{e}}+n_{t l} x_{0}+\left(\tilde{n}_{\mathrm{e}}+\tilde{n}_{\mathrm{e}} x_{0}\right) \sin \left(\omega_{\mathrm{p}} t-\right.\right.$ $\left.k_{\mathrm{p}} x_{0}\right)$ ) が存在するときの強度 $I_{a c x^{(1)}}{ }^{(1)}$ は，

$$
\begin{aligned}
I_{a c x^{(1)}}= & |B|^{2} e^{-u_{0}^{2}}\left[\Delta \phi _ { 0 } \left\{e^{-\left(u_{0}-\theta\right)^{2}}\right.\right. \\
& \left.-e^{-\left(u_{0}+\theta\right)^{2}}\right\} \cos \omega_{p} t \\
& -\Delta \phi_{1}\left\{e^{-\left(u_{0}-\theta\right)^{2}}\left(u_{0}-\theta\right)\right. \\
& \left.\left.+e^{-\left(u_{0}+\theta\right)^{2}}\left(u_{0}+\theta\right)\right\} \sin \omega_{p} t\right]
\end{aligned}
$$

ここで, $u_{0}=u-\left(\phi_{1} w_{0} / 2\right), \quad \phi_{1}=n_{01} r_{1} \lambda \Delta d$, $\Delta \phi_{0}=\tilde{n}_{0} r_{v} \lambda \Delta d, \Delta \phi_{1}=\tilde{n}_{a}$ w $w_{0} r_{t} \lambda \Delta d, x_{0}:$ ビ 一ムウェスト中心を原点としたときのプラズ

マ波動伝搬方向の座標

となり，プロファイル全体が $x_{0}$ 万向へ移動する。な お，測定対象亡なる密度摇動が定在波であるときは， フラウンホーファ回折の信号 $I_{a c}{ }^{(1)}$ は雾となる。従つ てフラウンホーファ回折法は，静電プロープによる波 動スペクトルあるいはゆらぎ強度の測定時にしばしば 問題とされる放電のふらつきなどの単振動的外乱成分 の妨害を受けない利点を持つ。また，静電プローブに よる測定データへの外乱成分の混入度合いの判定に利 用できる。

\section{TPS の観測 と検討}

〈3・1〉TPS の特性と構造 TPSは放電の維持 作用と密接な関係伅ある現象である。まず放電特性之 の関連性について観測結果を示す。次に, TPSの発 生位置およびステップ電位差の測定結果を，更に TPS での電子密度分布，速度分布関数の測定結果加ら巨視 的構造を明らかにする。

（1）放電特性と TPS の関係 本実験条件下で の放電電流 $I_{d}$ 対電生 $V_{d}$ 特性は，図 2 亿示すよjk 気体圧力 $p$ 亿強〈依存し，定電圧特性を示す領域 $[I]$

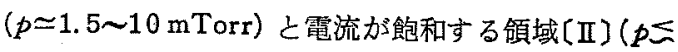
$0.8 \mathrm{mTorr}$ に分けられる。 
TPS は，上記〔エ〕の領域で明りょうに現われ，そ の発生位圆は同一笔流で珐力を低下させると陽極方向 八移動し，ついには放電領域に TPS が観測されなく なり，乙れに伴って電流対電任特性は領域( I)加ら領 域(II)八入る。その変化の様子を四 3 (圧力仁よる空 間電位 $V$ ，分布の変化）に示す。同四で $z$ は除極から の距髉である。

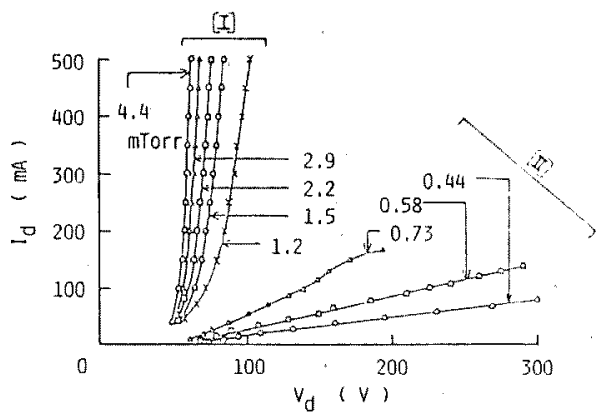

図 2 放電電流対放電電王特性

Fig. 2. Discharge current $I_{d}$-voltage $V_{d}$ characteristics $\left(I_{H}=9 \mathrm{~A}\right)$.

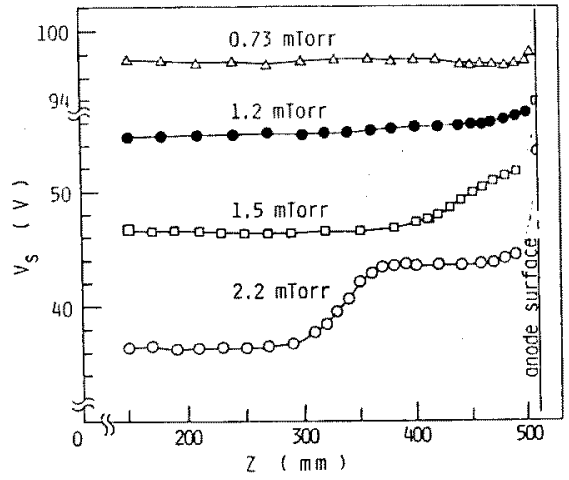

図3 作動気体王力による空間電位分布の変化

Fig. 3. Variation of spatial profiles of space potentials by working gas pressure $\left(I_{d}=500\right.$ $\mathrm{mA}, I_{H}=9 \mathrm{~A}$ ).

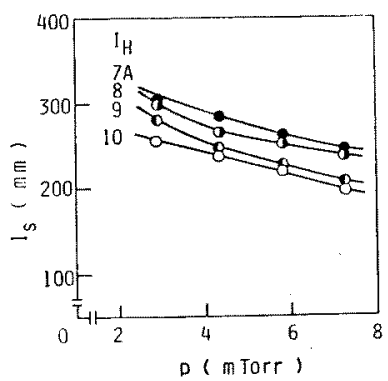

(a) $l_{s}-p$ 特怡 $\left(I_{d}=5(i, \mathrm{~mA})\right.$

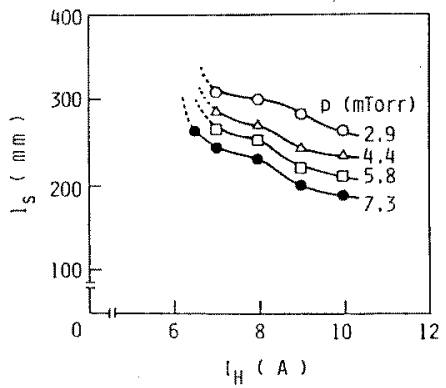

(b) $l_{s}-I_{B}$ 特狌 $\left(I_{d}=500 \mathrm{~mA}\right)$
表 1 各種ガスでのステップ值 $\Delta V$

Table 1. Step values $\Delta V$ for various gases.

\begin{tabular}{c|c|c|c|c}
\hline 気体O星類 & $\mathrm{Ar}$ & $\mathrm{N}$ & $\mathrm{H}$ & $\mathrm{He}$ \\
\hline$\Delta V(V)$ & $9 \pm 1$ & $9 \pm 1$ & $9 \pm 1$ & $14 \pm 1$ \\
\hline
\end{tabular}

（2）TPSの発生位算とステップ電位差 TPS の特性に影響を及ばす外部から制御できる放電パラメ 一夕は，気体の種類，気体正力 $p$, 放電電流 $I_{d}$, 㓌極

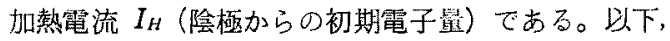
てれら四つのパラメータを変えて, TPS の特性(発生 位犆と電位差）および構造（電子密度分标，速度分布 関数)の詳細を示す。

まず，陰極加ら TPS までの距離 $l$ は は，図4（a） および(b)に示すように，pおよび $I_{H}$ によって変化 するが，放電電流の変化 $(200 〜 500 \mathrm{~mA})$ によってはは とんど変化しない〔図4(c))。

次に，ステップの電位差 $\Delta V$ は $p, I_{d}, I_{H}$ によっ てはほとんど变化を受けず，気体の種類（特汅，その 励起または電碓電王）に上る効果が大きい。各種気体 (Ar, N, H, He) に対する $\Delta V$ の測定值を表 1 に亦す。 $\mathrm{Ar}, \mathrm{N}, \mathrm{H}$ ではほほ同じ値 $(\Delta V \simeq 9 \pm 1 \mathrm{~V})$ で，一方， $\mathrm{He}$ では $\Delta V \simeq 14 \pm 1 \mathrm{~V}$ である。これらの気体の中で He のみが他のガスに比へ，その電離（または励起） 電玨が高い值であること，および各気体とも TPS で の加速後の平均エネルギー $\left(T_{\varepsilon} / e+\Delta V\right)$ は, 電離(ま たは励起）エネルギーに近い値上なり，電離（または 励起）に十分なエネルギーを持つ電子数が相当大きく 极ることなどから， $\Delta V$ の値は電離作用と密接関連 していると推定さ机る。

（3）電子密度招上び速度分有関数 放笔㧘流 $I_{d}$ $=500 \mathrm{~mA}$, 任力 $p=3,4.4,6 \mathrm{mTorr}$ のと立の放電 管中心軸上の空間雷位 $V$ ，電子密度 $n_{e 0}$ の值を测定 した。その結果， $n_{00}$ 分布はいずれる谷形の分布をし て抢り，最小密度の位置は，ちょうどTPSの電位立

図 $4 l, D$ 特 性

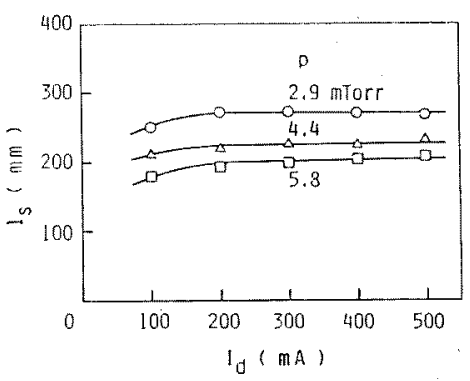

(c) $I_{s}-I_{d}$ 特性 $\left(I_{H}=9 \mathrm{~A}\right)$

Fig. 4. Characteristics of $l$. 


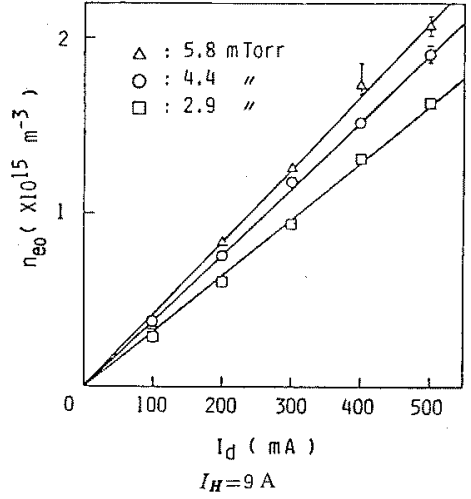

図 5 電子密度之放電電流の関係(領域 $(I])$

Fig. 5. Variation of electron densities $n_{e 0}$ by the change of discharge current $I_{d}$ in region (I).

上り開始点に対匛していることがわかった〔文献（5） 参照。

なお，陰極前面領域加ら TPS の前半部に至る領域 での軸方向执よび径方向の電子密度の空間的変化の測 定值は，近似的に次式で表わせる。

$$
n_{e}(r, z)=n_{e}^{*}\left\{1-(r / R)^{2}\right\} e^{-\alpha z}
$$

ただし， $n_{e}{ }^{*}, \alpha:$ 定数， $R$ : 管半径

また，升力領域が図の[I]にあるとき， $I_{d}$ を変化さ せて TPS の陰極側の点で $n_{e 0}$ の変化を測定すると図 5 が得られる。乙れから，各珐力条件下で $I_{d}$ の増加 により n,0 は直楾的に增加することがかかる。

次に，管軸上で軸方向の電子速度分布関数を両面プ ローブを用いて測定した。両面プローブは，2 枚の平 面プローブを背中合せに絶縁接合したもので，管軸に 両面加垂直になるように設定した。測定結果を図6に 示す。同図の横軸上の原点0を中心仁，右側书よび左 側の各図はそれぞれ陰極および陽極向けプローブによ る一次元速度分布の測定結果を示す。陰極側向けプロ 一ブでは，TPS での加速電子群扰よび新たに発生した 低速電子群（縦㛙近傍領域の電子群）が観測されてい る。图6亿执いて，TPS 部での速度分布関数のピーク 点 (加速電子群)の移動 $\Delta V_{E}$ を, 空間電位の変化 $\Delta V$, （ただし，TPSの低電位側電位を基準電位とする）に対 してプロットすると図 7 が得られる。各值は傾きが 1 の直線上にほぼ乗るのがわかる。

〈3.2〉 特性と構造に関する考察＼cjkstart本節では，前 節で得た結果からプラズマ不安定性に関する考察を行 ない，TPSの特性㧊よび構造がプラズマ不安定性に 基づくことを示す。

\section{（1）電子ドリフト不安定性電流による電子の}

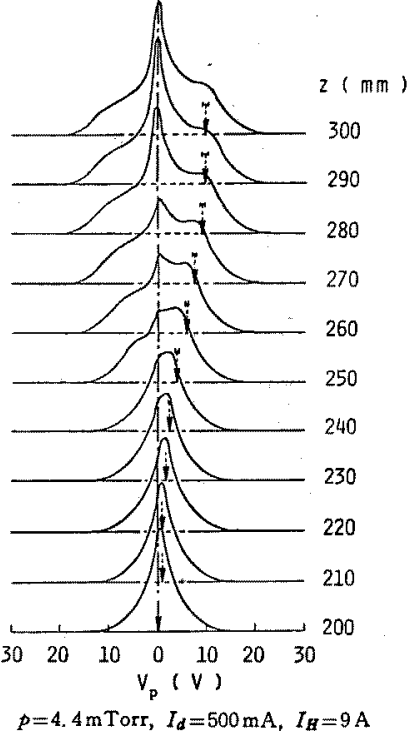

図 6 電子速度分布関数の軸方向変化

Fig. 6. Axial variation of electron velocity-distribution functions.

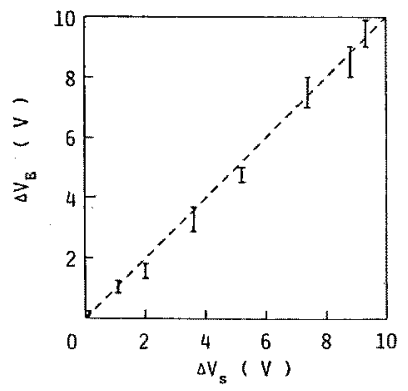

$p=4.4 \mathrm{~m}$ Torr, $I_{d}=500 \mathrm{~mA}, I_{B}=9 \mathrm{~A}$

図 7 TPS に上る䉓子群の加速

Fig. 7. Acceleration of electrons by TPS.

平均的ドリフト速度 $\bar{v}_{d}$ は，

$\bar{v}_{d}=I_{d} /\left(\bar{n}_{e} e \pi R^{2}\right)$

ただし， $\bar{n}_{\ell}$ : 管断面での平均電子密度

で与えられる。(3)式より，

$$
\bar{n}_{e} \equiv\left(1 / \pi R^{2}\right) \int_{0}^{R} n_{e}(r) 2 \pi r d r=n_{e 0} / 2
$$

となるので，(4)式の $\bar{v}_{d}$ と電子熱速度 $v_{\varepsilon}\left[\equiv\left(\kappa T_{s}\right)\right.$ $\left.m_{\bullet}\right)^{1 / 2}$ \}との比をとると，

$$
\bar{v}_{d} / v_{e}=\left(2 / e \pi R^{2}\right)\left(m_{e} / \kappa T_{e}\right)^{1 / 2}\left(I_{d} / n_{e 0}\right)
$$

となる。 $n_{\boldsymbol{c} 0}$ の測定值をむとに $\bar{v}_{d} / v_{a}$ の軸方向分布を 求めた結果, TPS の開始点で $\bar{v}_{d} / v_{\text {a }}$ は最大值を示 し，その值は $0.4 \sim 0.5$ 程度であるととが明らかとな 
った[文献 (5)参照]。本実験条件での電子ストリーミ ング不安定性の成長率 $\gamma^{(12)}$ 加ら， $v_{d} / v_{\varepsilon}<0.1$ では波動 の成長距離 (成長侍間 $(1 / \gamma)$ での伝搬距離 $\left(v_{p h} / \gamma ; v_{p h}\right.$ : 位相速度引として $10 \mathrm{~mm}$ 程度必要であるが， $v_{d} / v_{\text {。 }}$ $>0.4 \sim 0.5$ での最大成長率の波動は $1 \mathrm{~mm}$ 以下で軸

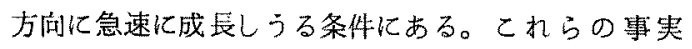
は，TPSが電子ストリーミング不安定性によって生 じる波動または乱れと密接に関連していることを示唆 している。窒素, ヘリウム，水素を用いた各実験でも $\bar{v}_{d} / v$ 。ひいてほぼ同じ測定結果が得られた。

（2）電子密度 図7 の観測事実より，（i TPS 領域でステップ電位差に対応した電子群の加速がある

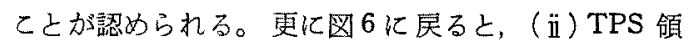
域ではそれらの加速電子群の電離作用により，新たに 低速の電子群が発生しているととがわかる。従って, $\langle 3.1\rangle$ 節で述べた軸方向の電子密度分布の谷形構造の うち，(i) 陽極側の電子密度の空間的增加は, TPSで の加速電子による励起・電離過程によるむのである。 他方, （i）陰極侧での電子密度の空間的減少は, 陰極 近傍領域で発生したプラズマ中の電子群が陽極方向一 ドリフトする過程で，主に管壁再結合による損失によ って生じる〔その結果として，(4)式により $\bar{v}_{d}$ の增 大をむたらすうすのである，と予測される。ただし， 陰極近傍領域から TPS に至る電位分布が平坦な領域 での, 電子密度の軸方向減少の減衰特性長 $(1 / \alpha)$ を, 軸方向の密度变化を考慮し，加電子速度分布関数を マクスゥェル分布に，径方向損失に両極性拡散效果ま たは自由落下効果を仮定して概算した值は，実験值 (80 100 mm 程度) より 4 5 倍小さい。従って, 密度 の減夜特性に関するより精密な定量的評価には，実効 的な電離衝突周波数を増大させる励起過程の効果また は少数の高速電子ビームの効果などを取入れなければ ならないと考えられる。

（3）発生位置 陰極加ら TPS の発生位置まで の距離 。は，図4(a)〜（c)に示したようにpおよ び $I_{H}$ の值によって変化するが，Idによっては変化し ない。この理由は，〈3.2〉節 (1)項で示したステップ 位置の決定条件 $\bar{v}_{d} / v_{\varepsilon} \simeq 0.4 \sim 0.5$ により説明すること ができる。すなわち，TPSより陰極側(ただし，陰極 近傍のシース域を除く)の一点 $P$ の電子温度 $T$ 。お よび密度 $n_{e 0}$ に注目した場合，T。は本実験条件の笧 囲で $p, I_{H}, I_{d}$ を変えてむほとんど変化しないが， $n_{e}$ は大きく変化する。例芫ば, 図5 5 亿示したように，p， $I_{H}$ は一定の条件の下で $I_{d}$ を変化させると，n,0 は直 線的に増加する。(6)式より $\bar{v}_{d} / v_{c} \propto I_{d} / n_{c 0} V \overline{T_{c}}$ であ るから, 点 $P$ での $\bar{v}_{d} / v$ 。 $I_{d}$ の変化によっては
変化せず, 従って $\bar{v}_{d} / v_{t} \simeq 0.4 \sim 0.5$ となる空間的位

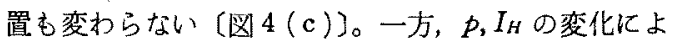
り $\bar{v}_{d} / v_{s} \approx 0.4 \sim 0.5$ となる空間的位置加移動するの で，そ㧈に忍じて TPS の発生位置も移動する。

\section{〈3.3〉TPS 領域でのプラズマ乱れの実験的検証}

ここでは, 以上の議諭のより直接的な実験的検踣よ して，TPS 領域でのプラズマ乱れ，特にそのモード およびゅらぎ強度に関する詳細測定の結果について述 べる。測定には静電プローブおよび $35 \mathrm{GHz}$ マイクロ 波を用いた。

笔子飽和領域にバイアスした静電プローブにより湘 定した，周波数スペクトルの軸方向の变化を図8に示 す。TPS 領域には，低周波 $(f<200 \mathrm{kHz})$ のコヒーレ ント波汃大きく発生している。各コヒーレント波に対 し、マイクロ波のフラウンホーファ回折法に上る測定 を行なった。各周波数のコヒーレント波に対し，前方 焦点面上で測定した信号プロファイルのピーク点の座 標 $u_{m}$ を求め， $u_{m}-\theta$ 面上にプロットした結果は，イオ ン音波の理論曲線に良く一致した[文献 (8)参照】。す なわち，測定された各コヒーレント波動は，伝搬形の イオン音波であると結論できる。一方，2本の静電プ ローブによりプラズマ波動の空間的位相変化を測定し た結果を図9亿示す。測定值は，イオン音波の理諭曲 線とほぼ一致しており，上記の結論が妥当なとと確 認した。

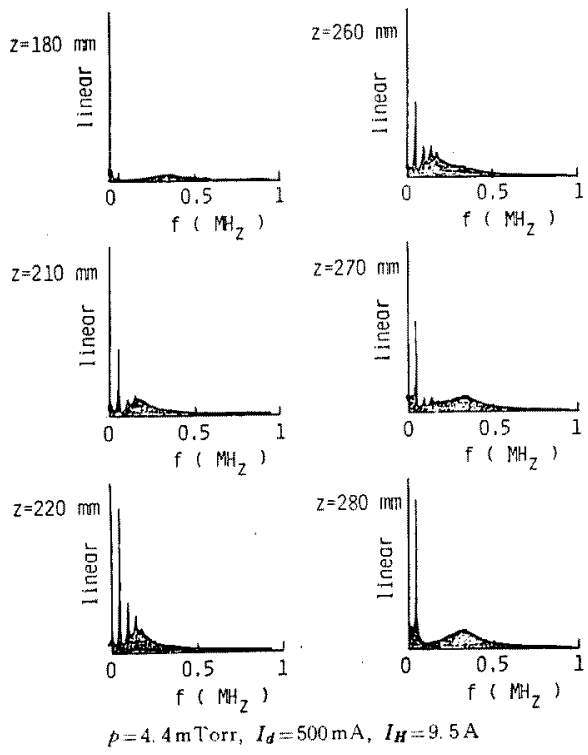

図 8 TPS 領域での波動の周波数 スペクトル

Fig. 8. Frequency spectra of waves in TPS region. 


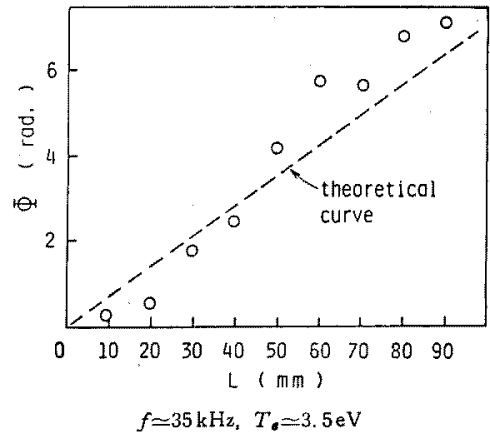

図 9 位相の空間的変化

Fig. 9. Spatial changes of phase $(\Phi)$.

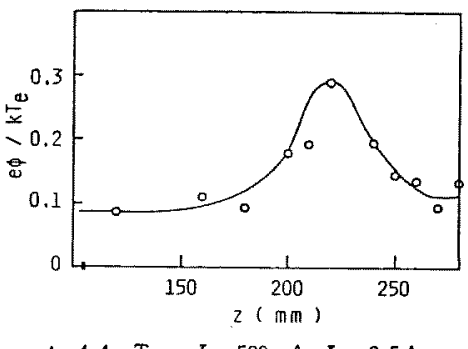

図 10 プラズマ乱強度の軸方向变化

Fig. 10. Axial variation of fluctuation intensities.

な拉，これらの低周波波動の成長機構を直接的に示 す測定結果は本実験では得ていないが，てれらの波動 は最大成長率で発生した波動のエネルギーが波上波の 非線形過程を経て長波長側へ移行した結果生じたもの と予想される。

次に, 電子飽和領域にバイアスした円柱形静電プロ ーブにより，管軸上のゆらぎ強度を測定した結果を四 10 に示す。なお，プローブ測定ではプラズマ波動の 電子密度の酒らぎのほかに，プラズマ不安定性とは別 の原因による放電の微小妕らぎなどの外乱をも一様に 取入れてしまう欠点肪古る。との点については，マイ クロ波フラウンホーファ回折法により，静電プロープ 信号の周波数スペクトル中の強い振幅を持つ各コヒー レント波が，上述のようにそれぞれ伝搬形のイオン音 波モードであることを確かめた。ゆらぎの強度は，図 10 のように TPS 部で最大值をとり，その值はおよ そ $e \phi / \kappa T_{*} \simeq \tilde{n}_{e} / n_{*} \simeq 0.3$ である。乙こで，陰極近傍領 域加ら TPS の発生開始点に至る領域和よび TPS 領 域で電雕が小さい前半部では，電子速度分布はほぼマ クスウェル分布をしているので， $\tilde{n}_{e} / n_{\mathrm{e}} \simeq e \phi / \kappa T$ ，と近 似できる。こ机らの測定值はレーザ共鳴散乱により得
られた測定結果 ${ }^{(6)}$ とも一致する。

ステップ部の異常抵抗（抵抗率 $\eta^{*}$ ) より求めた電 子の実効衙乫周波数は， $\nu^{*}=n_{e} e^{2} \eta^{*} / m_{\imath} \simeq 3 \times 10^{8} \mathrm{~Hz}$ て 古り，乙れは電子.中性粒子間の衝突周波数 $\nu_{e n} \simeq 6 \times$ $10^{6} \mathrm{~Hz}$ 亿比べ約 50 倍大きい。一方，無衝突衛撃波で のイオン音波乱流に対し奏験的に補正されたSagdeev の衝突周波数は $\nu_{s}=\left(10^{-12} / 12\right)\left(v_{d} / v_{\ell}\right)\left(T_{e} / T_{i}\right) \omega_{p e} \simeq 2$ $\times 10^{8} \mathrm{~Hz}$ となり， $\nu^{*}$ と非常に良い一致を示す。また 乱流スペクトルの仮定なしに, 乱れの強度から直接計 算される実効衝突周波数 עest は ${ }^{(13)}$,

$$
\nu_{e f f}=\omega_{p e}\left(W / n_{e} \kappa T_{e}\right)\left(\langle k\rangle \lambda_{D e}\right)
$$

ここで， $\omega_{p e}:$ 電子プラズマ周波数, $W:$ 波の エネルギー密度, 〈k〉: 平均波数, $\lambda_{D_{e}}$ : 電子 デバイ長

で血り，結局イオン音波に対して

$$
\nu_{e f f}=\omega_{p e}\left(e \phi / \kappa T_{e}\right)^{2}\left(\langle k\rangle \lambda_{D e}\right) \ldots
$$

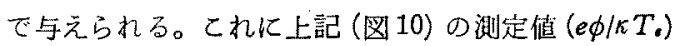
$\simeq 0.3$ を代入すると， Vess $\simeq 5 \times 10^{7} \mathrm{~Hz}$ となり $\nu^{*} の$ 約 $1 / 6$ の値が得られる。

てれらの結果 $\left(\nu^{*} \simeq \nu_{1} \sim \nu_{\text {ess }} \gg \nu_{e n}\right)$ は，プラズマ乱 れにより生じる電子の実効街突周波数の增大により， ステップ部の電界が十分維持されうると亡を示す。

$\langle 3.4\rangle$ 放電中での TPS の発生過程 以上の実 駼結果より，本実験条件下の直流放電中で観測される TPS 現象仙いて, その発生過程を以下の上うに姴 約するととができる。

(1) 䓡陰極近傍領域で生成されたプラズマ中の電 子は，㨁流放電を維持するため，放電管の陽極方向人 移動するにつれ，管壁再結合によりその密度が減少す る。

（2）密度の減少住対し，直流放電電流を維持する ため電子の平均ドリフト速度が上昇する。

(3) $\bar{v}_{d} / v_{\text {。 }}$ が $0.4 \sim 0.5$ 近くになると，プラズマ 波動の成長距離は $1 \mathrm{~mm}$ 以下となり, 強く励起されて プラズマ乱れが発生する。ここが TPS の低電位倪か らの電位上昇開始点となる。

（4）強いプラズマ乱れにより電子の実効衝突周 波数汃增大し，一定電流を維持するための電界強度 $E=\eta^{*} j$ が大きくなり，大きな電位とう配が生じる。

（5）電位こう配で加速された電子により，原子の 励起および電雇が活発になるので，放電発光量む多く なり，電子密度む上昇する。

（6）電子密度上帠により， $\bar{v}_{d} /$ V が $0.4 \sim 0.5$ 上 りずっと小さくなり，波動は減衰し，電位の上昇が止 ってTS の高電位側の平坦な電位分布が生じる。 


\section{4. 局所磁界による TPS の発生と制御}

以上の検討結果より, $\check{v}_{d} / v_{t} \approx 0.4 \sim 0.5$ になる点を 外部加ら制御することによって，TPSの発生位琶を 動かすとよができるかよ゙うかについて実䍄を行なっ た。すなわち，局所磁界を放電管外部加ら日加して $n$ 、の制御を行ない，そのときの TPS の挙勤を謂べ た。本実驗で印加した磁界の強さは，磁界コイル近 傍の放電領域で $10^{-3} \mathrm{~T}$ 以下程度で，電子ラーマ半 径 $r_{\text {e }}$ 扰よびイオンラーマ半径 $r_{i c}$ は，それぞれ $r_{\text {ac }}$ $>5 \mathrm{~mm}, r_{i c}>0.3 \mathrm{~m}$ である。磁界はりング状コイル によって生成されるので，コイル近傍ではいわゆる磁 気ミラー端に類似した磁界分布であるが，磁束はすべ てコイル心を中心としてコイル近傍のガラス壁を横切 る。従って，コイル近傍での電子の反射あるいは磁力 線に沿ったらせん運動で管壁へ歁かれることによる電 子の損失により，陰極領域からの供給プラズマの密度 を诚少させるこよができる。一方，TPSが発生して いる領域では $10^{-4} \mathrm{~T}$ 以下で $r_{0 c}>50 \mathrm{~mm}, r_{i c}>3 \mathrm{~m}$ となり，そこでの電子密度分布やイオン音波成長など に与える磁界の影響は無視できる。

〈4.1〉 発 生 〈3.1〉節で示したように, 1 $\mathrm{m}$ Torr 程度の庄力ではTPSが存在しない平理な電位 分布が観测されるが〔図 $11(\mathrm{a})$ )，飞の領域に局所磁 界を印加すると TPS が形成される〔図 12(a)】。こ の上き，電子密度分布は図 $12(\mathrm{a})$ 加ら図 $12(\mathrm{~b})$ 八变

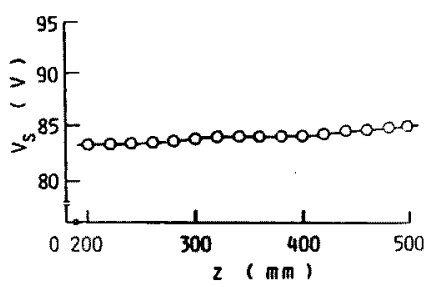

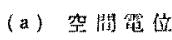

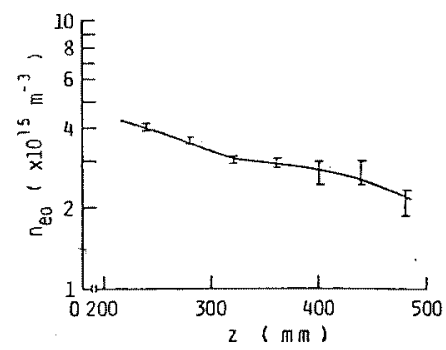

(b) 理子密度

$p=1 \mathrm{~m}$ Torr, $I_{d}=500 \mathrm{~mA}, I_{g}=9.5 \mathrm{~A}$

図 11 局所磁界印加前の $V_{s}$ と $n_{c 0}$ ○分布

Fig. 11. Distributions of $V$, and $n_{* 0}$ before applying local magnetic field.

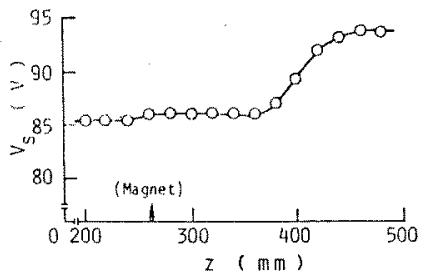

(a) 空閪電保

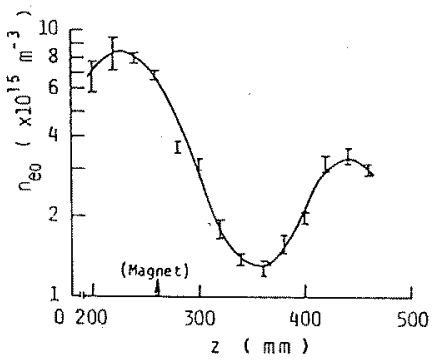

(b) 霆子密度

$p=1 \mathrm{~m}$ Tort, $I_{d}=500 \mathrm{~mA}, I_{H}=9.5 \mathrm{~A}$

図 12 局所磁界朋加後の $V$ ，之 $n_{e 0}$ の分布

Fig. 12. Distributions of $V$, and $n_{\epsilon}$ after applying local magnetic field.

わり，TPSの発生は強制的に密度を減少させた結果， 〈3.2〉節で述べた機構に起因して生じたすのとみるこ とができる。密度の最小值から求めた $\bar{v}_{d} / v$ 。值は 0.5 程塺で，自然発生の場合とほほ等しい。

〈4.2〉制御領域[I]の圧力条件下で, 目然 発生している TPS の陰極側領域で TPS から十分離 れた地点 $(z=190 \mathrm{~mm})$ に局所磁界用コイルを設置し， そのコイル電流 $I_{b}$ を変化させた。このときのTPSの 移動の椂子を図 13(a)〜 (c) (電位分布) および $(\mathrm{A})$ ～(C) (電子密度分布)に示す。なお，〈3.2〉節の結諭 加も推察されるように, 自然発生 TPS の陽極側領 域に磁界を印加して李，その位置を移動させることは できない。

困 13(a)〜 (c)より，I。が大きくなるに従いTPS が陰極僛八移勤しているのがわかる。また, 電子密度 の最小点むそれに対応して移動しており图 13(A) (C))，乙の值はいずれも $2 \times 10^{15} \mathrm{~m}^{-3}$ 程度で， $\bar{v}_{d}$ I $v_{\iota} \simeq 0.5$ である。なお，图 $13(\mathrm{~b})$ ，(c)の状態で測定 した電子速度分方関数の空間的（軸方向）变化は， (a) 図の状態 $\left(I_{b}=0\right)$ での测定結果比比へ, TPSの 移動に伴う相対的位置は变化しているものの, 電子密 度減少 $\rightarrow$ TPS 発生 $\rightarrow$ 初期電子群の加㯈一電雇增大之 いう特性は同じであり，TPS およびそこでの電子群 に対しては，磁界が本質的変化を引き起ししていない こと磪認した。

以上の測定結果は，〈3.4〉節の結諭の確証を与える ものであり，一方 TPS の制御が局所磁界印加により 

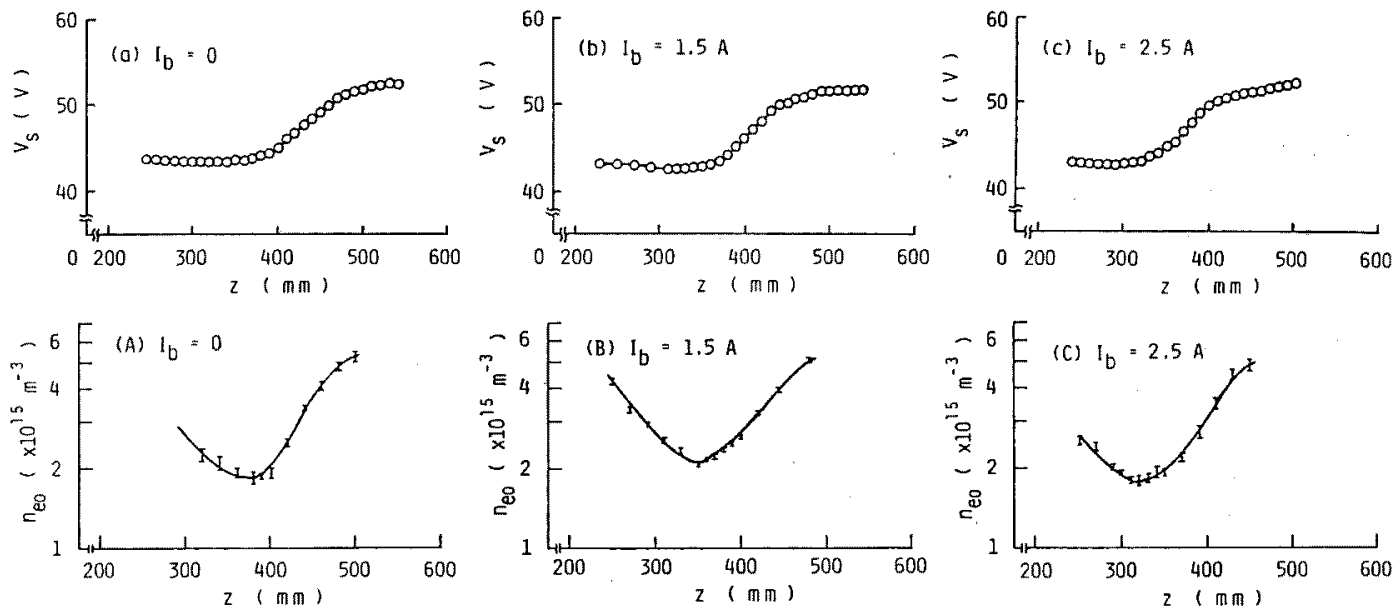

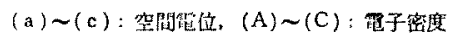
$p=2.5 \mathrm{mTorr}, I_{d}=500 \mathrm{~mA}, I_{H}=9.5 \mathrm{~A}$

図 13 局所磁界沙よる TPS の制御

Fig. 13. Control of TPS by local magnetic field.

可能であるてとを示している。

\section{5.むすび}

数 $\mathrm{mT}$ Torr 程度の低圧力条件下の 熱陰極形直流放電 中に，しま状の不均一発光を伴い，かつプラズマ不安 定性上密接阅関連したポテンシャルステップが発生す るのが観測された。その発生・維持機構の解明のた め，静電プローブやマイクロ波フラウンホーファ回折 法によるプラズマの構造およびプラズマ乱れなどに関 する詳細測定と，その考察を行なった。

その結果，直流放電中でのポテンシャルステップの 発生が，放電維持のための電子ストリーミングによっ て励起されたプラズマ乱れにより説明できることを明 らかにした。

更に，その結論に基づき，乱流ポテンシャルステッ プの発生およびその位置の制御か，放電空間への局所 磁界印加により可能であることを実験的に示した。 (昭和 57 年 11 月 22 日受付, 同 58 年 3 月 10 日再受付)

\section{文献}

(1) L. Pekarek: "Ionization Waves (Striations) in a Discharge Plasma", Sov. Phys. Usp, 11, 188 (1968)

(2) P.S. Landa, N. A. Miskinova \& Yu. V. Ponomarev: "Ionization Waves in Low-Temperature Plasmas", ibid., 23. 813 (1980)
(3) A. Garscadden : Gaseous Electronics (eds. M. N. Hirsh \& H. L. Oskam) 1, 65 (1978) Academic, New York

(4) P. J. Palmadesso \& K. Papadopoulos (eds.): Wave Instabilities in Space Plasmas p. 129 (1979) D. Reidel Pub. Co., Dordrecht

(5) Y. Sonoda, K. Maeyama, K. Muraoka \& M. Akazaki : "Development of Local Potential Step in DC Discharge by Streaming Instability", Japan J. Appl. Phys., 20, 1177 (1981)

(6) K. Uchino, M. Maeda, K. Koga, Y. Sonoda, K. Muraoka \& M. Akazaki ; "Laser Resonance Scattering Studies of the Development of a Potential Step in a Low-Density DC Discharge in Hydrogen", ibid., 21, 906 (1982)

(7) Y. Sonoda, K. Uchino, K. Muraoka \& M. Akazaki : "Microwave and Laser Resonance Scattering Studies of Development of Potential Step in DC Discharge at Low Pressure", Proc. Int. Conf. on Plasma Phys, Goteborg, p. 249 (1982)

（8）内田・小岛：「䉓子エネルギー分布の測定」, 理研シンポシウ ム・ガスプラズマ中のプローブ測定，p.54 (昭 44-3)

(9) Y. Sonoda, A. Sakurai, K. Muraoka \& M. Akazaki : "Measurement of Plasma Waves by Fraunhofer Diffraction Method in Microwave Region", Japan J. Appl. Phys,, 21, L 372 (1982)

(10) M. von Hellermann, A. Murdoch \& D. E. Evans: "Far Forward Scattering at 10 Microns for Toska Tokamak", 5 th Int. Conf. on Infrared \& Millimetre Waves, p. 270 (1980)

(11) D. E. Evans, M. von Hellermann \& E. Holzhauer : "Fourier Optics Approach to Far Forward Scattering and Related Refractive Index Phenomena in Laboratory Plasmas", Plasma Phys., 24, 819 (1982)

(12) T. E. Stringer : "Electrostatic Instabilities in CurrentCarrying and Counterstreaming Plasmas", Plasma Phys., 6. 267 (1964)

(13) A. A. Galeev \& R. Z. Sagdeev : "Nonlinear Plasma Theory", Rev. Plasma Phys. (ed. A.M. A. Leontovich) 7. 146 (1979) Consultants Bureau, New York 